JOLANTA M. MARSZALSKA* - WARSZAWA

\title{
KILKA UWAG O POTRZEBIE PRAGMATYCZNEJ PIŚMIENNOŚCI W ŚREDNIOWIECZNYCH KLASZTORACH MONASTYCZNYCH
}

Pisanie, czytanie, nauczanie i myślenie to składniki jednego i tego samego celu intelektualnego i moralnego, którym było zachowanie wiecznej wartości. $\mathrm{W}$ regule św. Benedykta oraz $\mathrm{W}$ zdecydowanej większości ksiąg średniowiecznych wyrażenie sicut scriptum est (jak jest napisane) odnosiło się tylko do jednej księgi - do Biblii. W tym przypadku pisanie oznaczało coś więcej niż wyuczoną trudną sztukę kopiowania, oznaczało utrwalanie Słowa Bożego. Oczywiste jest więc, że średniowieczni mnisi benedyktyńscy i cysterscy troszczyli się o jakość biblijnej tradycji rękopiśmiennej, każda bowiem kolejna kopia oznaczała większą liczbę błędów w tekście. W każdym innym tekście nieuchronne pomyłki ludzkiej ręki mogły przeszkodzić w jego zrozumieniu lub obrazić samego użytkownika, lecz w Biblii stanowiły już pogwałcenie Bożego Słowa. W centrum orientacji życiowej średniowiecznego mnicha znajdowało się bez wątpienia Pismo Święte za pośrednictwem którego, mnich zgłębiał Boże objawienie a także oddawał chwałę Bogu przez sprawowaną liturgię. Chrześcijaństwo było bowiem religią księgi świętej i fakt ten decydująco określał charakter całej kultury piśmiennej W średniowieczu. W kulturze chrześcijańskiej pismo i księga jako nośnik Boskiego objawienia, zdobyły godność i dostojeństwo jakich nie osiągnął nigdy żaden tekst lub dzieło literackie w społeczeństwie antycznego świata rzymskiego.

Pisanie zakłada pewną ciągłość. Księga była zawsze cennym skarbem, który należało zachować dla przyszłych pokoleń. Często jej format, oprawa i sztuka zdobienia podkreślały wieczną wartość jej treści. Toteż Biblia, Pisma Ojców Kościoła, żywoty świętych czy księgi liturgiczne, miały niejako być pod ręką, miały być zawsze w użyciu. Przywileje i inne pisma, w tym dokumenty które postrzegano jako należące do rozległej dziedziny prawa i administracji zawdzięczały swą wagę odwiecznemu istnieniu opactw oraz ciągłości wspólnych interesów.

Obcowanie ze świętymi tekstami księgami miało w łacińskim średniowieczu monastycznym - swoje określone formy. Dokonywało się to zawsze przez indywidualne czytanie i słuchanie głośno czytanych tekstów, objaśnianie tekstów świętych i płynących z nich nauk, pouczeń. Przy tym trzeba pamiętać, że w śred-

*Jolanta M. Marszalska - prof. dr hab. historii, Instytut Nauk Historycznych UKSW w Warszawie. 
niowiecznej tradycji monastycznej czytanie (lectio), łączyło się ściśle z rozważaniem, medytacją. Wspominał już o tym Beda Venerabilis (zm. 735), powołując się na słowa Pawła Apostoła, pisząc o konieczności „usilnego i wytrwałego czytania i rozważania Pisma Świętego"”.

Podobnie Hugo od św. Wiktora (zm. 1141), w swoim wprowadzeniu do studium filozofii i teologii (Didascalion) stwierdził, że czytanie (lectio) musi uzupełniać rozważanie (meditatio), i tylko w ten sposób studiowanie tekstu daje pożytek moralny ${ }^{2}$.

Z kolei Guido Kartuz dowodził w swojej „Scala claustralium” napisanej około połowy XII wieku, że czytanie - to jest „,pracowite rozważanie Pism z wielką uwagą", które powinno prowadzić do całkowitej przemiany człowieka, należy je bowiem zawsze łączyć z rozmyślaniem, modlitwą i kontemplacją. Stąd owe średniowieczne: meditatio, oratio, contemplatio ${ }^{3}$.

Treścią kultury piśmiennej średniowiecza, obok czytania i medytacji dzieł teologicznych było również kopiowanie podstawowych tekstów religijnych, bowiem w powszechnej opinii średniowiecznej kultury, istniało głęboko zakorzenione przekonanie, że pisanie kodeksu jest dobrym uczynkiem, który przynieść może zbawienie kopiście, co wyrażało się w maksymie: dentur pro penna scriptori celica regna, lub nomen scriptoris salvet Deus omnibus horis.

Jak już zaznaczono rozwinięta we wczesnym średniowieczu intensywna kultura piśmienna objęła swoim oddziaływaniem nade wszystko obszar sakralny i religijny. Zmiana zasadnicza, zwana powszechnie wielkim przełomem w kulturze piśmiennej Europy łacińskiej nastąpiła na styku XII i XIII stulecia. Pojawiła się wówczas pragmatyczna piśmienność. Obok bowiem uprawianej dalej z powodzeniem piśmienności sakralnej, głównie w skryptoriach klasztornych i katedralnych zaczyna rozwijać się piśmienność praktyczna, służąca usprawnieniu życia codziennego, nade wszystko życia polityczno-gospodarczego ówczesnej Europy. Dokonało się to $\mathrm{w}$ szerokim kontekście ważnych przeobrażeń instytucjonalnych i intelektualnych występujących w społeczeństwie i kulturze Europy na przestrzeni prawie trzech wieków. Warto wymienić tu tylko najważniejsze procesy, które doprowadziły do wyodrębnienia się zjawiska piśmienności pragmatycznej, tak bardzo ważnej w nowoczesnym społeczeństwie europejskiego średniowiecza. Był to bez wątpienia rozwój nowych metod poznawania i rozumienia świata, powstawanie nowego typu szkół, w szczególności uniwersytetów, które szybko stały się ważnymi ośrodkami kultury piśmiennej i wiedzy czerpanej z ksiąg. Dalej zachodzące zmiany instytucjonalne w kościele, które zakładały m.in. oparcie życia kościelnego na ujednoliconym prawie, czy wreszcie kształtowanie się nowej koncepcji państwa. Stąd przywileje stanowe i dokonująca się standaryzacja prawa dzięki tekstom pisanym a także tworzenie całego systemu prawnego opartego na słowie

${ }^{1}$ B. Venerabilis, In primam partem Samuelis libri III. Prologus, w: Corpus Christianorum. Series Latina, Turnohalti 1962, k. 9.

${ }^{2}$ M. J. Carruthers, The Book of Memory. A Study of Memory in Medieval Culture, Cambridge 1996, s. 186.

${ }^{3}$ Drabina do raju, czyli traktat o sposobie modlitwy rozdz. I, II, XI, XII, w: Lectio Divina. Boże czytanie, Tyniec-Kraków 1991, s. 58-60, 71-73. 
pisanym. ${ }^{4}$ Nosicielami tej nowej kultury piśmiennej, stali się ludzie, którzy w szkołach nowego typu, jakimi były uniwersytety, otrzymali określoną formację intelektualną. Było nią umiejętne posługiwanie się wiedzą zdobytą w księgach, a także przyswojenie sobie nowych metod racjonalnego myślenia i poznania. $\mathrm{Z}$ udziałem pierwszych intelektualnych elit europejskiego średniowiecza, nowe formy piśmienności rozwijane były w kurii papieskiej w skryptoriach, dworach królewskich i książęcych, słowem w społecznościach miejskich ówczesnego mikroświata.

Badania nad monastycyzmem ( $\mathrm{z}$ wielką intensywnością prowadzone $\mathrm{w}$ ostatnich latach), niezbicie dowodzą, iż pragmatyczna piśmienność znalazła swoje pełne odzwierciedlenie w życiu klasztorów benedyktyńskich i cysterskich środkowego i schyłkowego średniowiecza ${ }^{5}$. Jej ślady można odnaleźć już w Regule św. Benedykta z Nursji, co z pewnością było reliktem antycznego jeszcze modelu użytkowania pisma. Tak więc w rozdziale „O narzędziach i innych przedmiotach należących do klasztoru" czytamy, że opat powinien prowadzić spis tych rzeczy, które daje w użytkowanie braciom ${ }^{6}$. Wśród rzeczy niezbędnych do życia zakonodawca wylicza również rylec (graphium) oraz tabliczki do pisania (tabula) ${ }^{7}$. Tabliczki powleczone woskiem służyły do czynionych wprawną ręką mnicha codziennych notatek, rozliczeń gospodarczych czy szkiców granic użytkowanej $\mathrm{w}$ nadaniach ziemi. Jako swoistą w wymowie ciekawostkę warto przytoczyć fakt, iż opat benedyktynów z Bourgueil, Balderyk (zm. 1130), zarazem jeden z ciekawszych poetów przełomu XI/XII wieku, poświęcił kilka utworów wierszowanych, służących pochwale owych niezbędnych przyborów pisarskich tj. rylca i tabliczek, bez których nie podobna wyobrazić sobie średniowiecznego mnicha i jego pragmatycznej piśmienności ${ }^{8}$. Jednakże najbardziej typowym przykładem piśmienności o charakterze pragmatycznym było użycie w klasztorach monastycznych tekstów pisanych (głównie dokumentów), służących do zabezpieczenia posiadłości klasztornych, rozlicznych aktów nadania ziemi, darowizn, kupna, sprzedaży, zamiany bądź dzierżawy. A zatem owa piśmienność pragmatyczna była niezbędna w całej szerokiej panoramie gospodarczej i prawnej służącej do zarządzania majątkiem klasztornym.

To „upiśmiennianie” gospodarki klasztornej było częścią znacznie szerszego zjawiska. Wiązało się bowiem bardzo ściśle ze wzrastającą rolą świadectwa pisanego w życiu społeczno-prawnym środkowego i późnego średniowiecza, mając również swoje historyczne odniesienie do polskiej rzeczywistości monastycznej

${ }^{4}$ E. Potkowski, Problemy kultury piśmiennej łacińskiego średniowiecznego, „Przegląd Humanistyczny", 38 (1994) s. 21-40.

${ }^{5}$ H. Keller, G. Gruhnuller, N. Stanbach (wyd.) Pragmatische Schriftlichkeit im Mittelalter, Erscheinungsformen, Munchen 1992, s. 37-79.

${ }^{6}$ Św. Benedykt z Nursji, Reguła, Tyniec-Kraków 1994, rozdz. XXXII, s. 144-145.

${ }^{7}$ Tamże.

${ }^{8}$ Potkowski, Problemy kultury piśmiennej łacińskiego średniowiecznego, s. 38; M. Manitius, Geschichte der laternischen litaratur des mittelalters, t. 3, München 1931, s. 890-891. 
przełomu XII/XIII stulecia ${ }^{9}$, bowiem na fakt zainteresowania mnichów tynieckich dokumentacją pisaną od początku istnienia opactwa, zwróciła już uwagę przed wojną Zofia Kozłowska-Budkowa, omawiając dyskusję dotyczącą dokumentu legata dla Tyńca (1123-1125). Badaczka wskazała wówczas na możliwość istnienia od samych początków archiwum klasztornego w którym zapewne gromadzono zapiski o pierwszych nadaniach majątkowych dla opactwa ${ }^{10}$. Pragmatyczna piśmienność w dziedzinie podejmowanych działań gospodarczych średniowiecznych klasztorów monastycznych, to nie tylko dbałość o dokumenty, pisane poświadczenia wszelakich darowizn, zamian gruntów czy ich sprzedaży, to również działalność na płaszczyźnie piśmienności normatywnej, która obejmowała całą organizację życia wewnątrz klasztornego, regulowana poprzez ustanawiane i zapisywane statuty. Przykładem niech będą statuty wydane przez opata klasztoru benedyktynów w Cluny, Hugona V (1205/1206), które zawierały między innymi informacje o obowiązku przygotowania sprawozdań gospodarczych na kapituły generalne a także jak prowadzić księgi gospodarcze, by ograniczyć samowolę, bądź swobodę działania złego zarządcy (libertas male ministrantium) ${ }^{11}$.

Cel pragmatyczny tego typu tekstów dotyczących zarządu gospodarczego i normatywnego jest aż nadto wyraźny. Zarówno u benedyktynów jak i cystersów, spisywanie, inwentaryzowanie majątku klasztornego zabezpieczało stan posiadania klasztoru (od momentu fundacji), notowanie zaś jego wydatków i przychodów (tzw. excerpta i percepta) pozwalało na prowadzenie racjonalnej gospodarki na wielu obszarach oraz na kalkulowaniu kosztów utrzymania konwentu. Stosowana i zalecana w klasztorach monastycznych piśmienność pragmatyczna w zakresie gospodarki klasztornej miała również zapobiegać potencjalnym konfliktom między opatem a konwentem, a tych nigdy nie brakowało w ciągu wieków.

Warto zaznaczyć, iż działalność gospodarcza średniowiecznych klasztorów monastycznych nie była bynajmniej jedynym i wyłącznym obszarem stosowania pragmatycznej piśmienności. Niedawne studia Karla Schreinera czy Georga Melleville'a ukazały rolę różnego rodzaju tekstów pisanych, niezbędnych przy organizowaniu życia religijnego wspólnot klasztornych, a także budowania struktur instytucjonalnych między klasztorami „środkowego" i późnego średniowiecza, oraz podejmowania wysiłków nad ujednoliceniem myśli teologicznej i jej rozpowszechniania.

Jednym z takich obszarów pragmatycznej piśmienności klasztorów monastycznych są m. in. Consuetudines klasztorne, które obok zapisanej Reguły św. Benedykta - określały życie liturgiczne i religijne wspólnoty, kształtowały formy indywidualnej ascezy i duchowości mnichów. Consuetudines - czyli klasztorne zwyczaje, początkowo wypracowane przez uczniów i przyswajane przez człon-

${ }^{9}$ S. Kętrzyński, Zarys nauki o dokumencie wieków średnich, Warszawa 1934, s. 207-247; E. Potkowski, Pismo i spoleczeństwo w Polsce późnego średniowiecza, „Przegląd Humanistyczny”, 22 (1978) z. 12, s. 35-52.

${ }^{10}$ Z. Kozłowska-Budkowa, Repertorium polskich dokumentów doby Piastowskiej, Kraków 1937, nr 26-32.

${ }^{11}$ Statuts, chapitres generaux et visites de L'Ordre de Cluny, wyd. G. Chavrin, Paris 1965, s. $57-$ 59. 
ków konwentu, z czasem (od X wieku począwszy) coraz częściej były zapisywane i uzupełniane z inicjatywy samych opatów i konwentów. Początkowo zawierały normy etyczne, prawne i religijne, regulujące życie w obrębie jednej wspólnoty monastycznej, z czasem - jak pokazuje to przykład kluniaków - Consuetudines mogły być korygowane, zmieniane i uzupełniane przez każdą wspólnotę klasztorną. Stopniowo, w miarę tworzenia się silniejszych związków między klasztorami, monastyczna consuetudo podobnie, jak Reguła św. Benedykta stała się normą prawną ${ }^{12}$.Byłaonabezwątpieniaważnyminstrumentemzachowaniajednościizwiązków między klasztorami, wprowadzała tak ważną jednolitość we wszystkich dziedzinach życia klasztornego.

Warto jeszcze zatrzymać się choćby na moment przy funkcji pragmatycznej historiografii monastycznej. Jej rola jest nieoceniona. Tworzenie bowiem spójnych wyobrażeń historycznych, szczególnie jednolitego obrazu początków zakonu lub klasztoru i dziejów wspólnoty zakonnej było swoistym instrumentem budowania i podtrzymywania a także identyfikacji wspólnoty monastycznej. Wszelakie kroniki, kopiarze dokumentów, czy księgi składanych uroczyście ślubów wieczystych, to nieocenione źródła do badań poszczególnych wspólnot monastycznych. Obrazuje to wypowiedź sprzed kilku wieków, Günthera z Nordhasen, opata klasztoru św. Piotra w Erfurcie, który napisał osobny traktat o pożytkach poznania i pisania historii (De Historia, 1481). Pisał do swoich współbraci ze zreformowanych klasztorów benedyktyńskich, że bez historii człowiek nie jest człowiekiem, bez historii mnich nie jest mnichem i bez niej nikt nie może zostać zbawiony (sine historiae homo non est homo, sine ea non sumus monachi, imo sine ea nemo potest salvari aeternum) ${ }^{13}$.

Innym obszarem stosowania piśmienności pragmatycznej w średniowiecznych wspólnotach monastycznych była korespondencja. Należały do niej tzw. litterae authenticae, czyli świadectwa prawego pochodzenia (de legitimo thoro) wymagane w niektórych wspólnotach zakonnych przy przyjęciu kandydata do klasztoru. Innym rodzajem były litterae testimoniales, spełniające funkcję listu polecającego lub czegoś w rodzaju „paszportu”, który miał ułatwić częste podróże, bądź otrzymanie gościny w obcym klasztorze. O takich listach wspomina także Reguła św. Benedykta.

W średniowiecznych klasztorach monastycznych przykładem stosowania pisma w relacjach wewnątrz klasztornych były pisane ręcznie formuły składanych ślubów zakonnych, tzw. karty profesji wieczystych. Reguła benedyktyńska jednakowa dla wspólnot monastycznch, przewidywała stosowanie takich pisemnych przyrzeczeń, oraz zachowania zasad życia klasztornego przy przyjmowaniu do wspólnoty nowych braci. Nowicjusz pisał je zawsze własnoręcznie lub tylko sygnował, składano je następnie na ołtarzu i przechowywano w klasztorze.

Listy czy polecenia były również ważnym obszarem działalności kopistów $\mathrm{w}$ średniowiecznych klasztorach monastycznych a potrzeba pragmatycznej piśmienności stawała się powoli nieuniknioną koniecznością.

${ }^{12}$ L. Donnat, Les coutumens monastiques autour de l'an Mil, w: D. Iogna-Prat, J. Ch. Picard, Religion et culture autour de l'an Mil, Paris 1990, s. 17-24.

${ }^{13}$ B. Frank, Das Erfurter Peterskloster im Klosterreform, Göttingen 1979, s. 385. 
Zawsze praca nad tekstem w skryptorium klasztornym była pewnym utrudzeniem, bez względu na to, czy kopiowano dzieła średniowiecznych teologów czy też skrupulatnie zapisywano wszelkie akty normatywne regulujące działalność gospodarczą klasztoru.

I jakże wielkiej aktualności nabierają słowa zapisane przez nieznanego z imienia zakonnika, niewielkiego opactwa cysterskiego w Szczyrzycu, który na kopiowanym przez siebie Antyfonarzu w 1609 roku zanotowat: Scribere qui nescit nullum putat esse, laborem tres digiti scribunt et totum corpus laborat (dla tego, kto nie rozumie pisanie nie jest pracą, a tymczasem chociaż trzy palce piszą, to jednak całe ciało się mozoli) ${ }^{14}$.

I trudno, po upływie kilku wieków od chwili zapisania tego wymownego stwierdzenia nie zgodzić się z prawdą jaką w sobie zawiera.

\title{
SOME REMARKS ABOUT THE NEED FOR PRAGMATIC LITERACY IN MEDIEVAL MONASTERIES
}

\begin{abstract}
Summary
Copying the basic religious texts, apart from reading and meditating theological works, constituted the content of literate culture of the Middle Ages, as in the popular medieval culture there was a deep-rooted belief that writing a code is a good deed that can bring salvation to copyists.

Developed in the early Middle Ages, intensive literate culture affected, above all, the sacred and religious sphere. The vital change, commonly known as a great breakthrough in the literate culture of Latin Europe, occurred at the turn of the twelfth and thirteenth centuries. Then the pragmatic literacy came into being. Apart from religious literacy, still popular especially in monastic and cathedral scriptoria, practical literacy began to develop, which contributed to the improvement of daily life, mainly, political and economic life in Europe at that time. This process happened in the broad context of important institutional and intellectual transformations occurring in the European society and culture for nearly three centuries.
\end{abstract}

Translated by Aneta Kiper

${ }^{14}$ J. M. Marszalska, Biblioteka opactwa cystersów w Szczyrzycu do końca XIX stulecia. Dziedzictwo wieków, Tarnów 2007, s. 87-88; Antiphonale cysterskie de Tempore, 1609, Arch. i BOCis, sygn. rkps muz. B.III.2; inw. 687; BN/mf.: 93985. 